Sección Básica / Basic

Nota científica / Scientific note

\title{
Bottom-up effects on arthropod communities in Platycyamus regnellii (Fabaceae) fertilized with dehydrated sewage sludge
}

\author{
Efectos ascendentes en las comunidades de artrópodos de Platycyamus regnellii \\ (Fabaceae) fertilizados con lodo de aguas residuales
}

\begin{abstract}
GEZILENE FERNANDES DE SOUZA ${ }^{1}$; GERMANO LEÃO DEMOLIN LEITE ${ }^{2}$; FARLEY WILLIAM SOUZA SILVA ${ }^{3}$; JÚLIA LETÍCIA SILVA ${ }^{4}$; REGYNALDO ARRUDA SAMPAIO ${ }^{5}$; GUSTAVO LEAL TEIXEIRA ${ }^{6}$; MARCUS ALVARENGA SOARES $^{7}$; JOSÉ COLA ZANUNCIO ${ }^{8}$
\end{abstract}

\begin{abstract}
${ }^{1}$ Biologist, Professor, Universidade Federal de Minas Gerais (UFMG) - Instituto de Ciências Agrárias, Avenida Universitária, 1.000, Bairro Universitário, CEP: 39404-547, Montes Claros, Minas Gerais, Brazil, geisyfernandes05@gmail.com, https://orcid.org/0000-0003-3500-1030. ${ }^{2}$ Ph. D. Professor, Universidade Federal de Minas Gerais (UFMG) - Instituto de Ciências Agrárias, Avenida Universitária, 1.000, Bairro Universitário, CEP: 39404-547, Montes Claros, Minas Gerais, Brazil, germano.demolin@gmail.com, https://orcid.org/0000-0002-2928-3193. ${ }^{3} \mathrm{Ph}$. D. Professor, Universidade Federal do Acre (UFAC) - Campus Rio Branco, Rodovia BR 364, Km 04, Distrito Industrial, CEP: 69920-900, Rio Branco, Acre, Brazil, farleyw@gmail.com, https://orcid.org/0000-0002-2651-9375. ${ }^{4}$ M. Sc. Professor, Universidade Federal de Minas Gerais (UFMG) - Instituto de Ciências Agrárias, Avenida Universitária, 1.000, Bairro Universitário, CEP: 39404-547, Montes Claros, Minas Gerais, Brazil, julialeticiasilva16@gmail.com, https://orcid.org/0000-0002-4394-1578. ${ }^{5}$ Ph. D. Professor, Universidade Federal de Minas Gerais (UFMG) - Instituto de Ciências Agrárias, Avenida Universitária, 1.000, Bairro Universitário, CEP: 39404-547, Montes Claros, Minas Gerais, Brazil, sampaio@ufmg.edu.br, https://orcid.org/0000-0003-3214-6111. ${ }^{6} \mathrm{Ph}$. D. Professor, Universidade Federal de Minas Gerais (UFMG) - Instituto de Ciências Agrárias, Avenida Universitária, 1.000, Bairro Universitário, CEP: 39404-547, Montes Claros, Minas Gerais, Brazil, lealtex@gmail.com, https:// orcid.org/0000-0001-7293-0790. ${ }^{7}$ Ph. D., Professor, Universidade Federal dos Vales do Jequitinhonha e Mucuri (UFVJM) - Campus JK - Rodovia MGT 367 $\mathrm{Km}$ 583, $\mathrm{n}^{\circ}$ 5000, Alto da Jacuba, CEP 39100-000, Diamantina, Minas Gerais, Brazil, marcusasoares@yahoo.com.br, https://orcid.org/0000-0002-8725-3697. ${ }^{8}$ Ph. D., Departamento de Entomologia/BIOAGRO, Universidade Federal de Viçosa, 36571-000, Viçosa, Minas Gerais, Brazil, zanuncio@ufv.br, https://orcid. org/0000-0003-2026-281X.
\end{abstract}

\section{Corresponding author}

Farley William Souza Silva. Ph. D. Professor, Universidade Federal do Acre (UFAC) - Campus Rio Branco, Rodovia BR 364, Km 04, Distrito Industrial, CEP: 69920-900, Rio Branco, Acre, Brazil.farleyw@gmail.com, https://orcid. org/0000-0002-2651-9375.

Suggested citation

SOUZA, G. F.; LEITE, G. L. D.; SILVA, F. W. S.; SILVA, J. L.; SAMPAIO, R. A.; TEXEIRA, G. L.; SOARES, M. A.; ZANUNCIO, J. C. 2021. Bottom-up effects on arthropod communities in Platycyamus regnellii (Fabaceae) fertilized with dehydrated sewage sludge. Revista Colombiana de Entomología 47 (1): e8943. https://doi.org/10.25100/socolen.v47i1.8943

Received: 20-Feb-2020

Accepted: 07-Nov-2020

Published: 29-Jun-2021

Revista Colombiana de Entomología ISSN (Print): 0120-0488

ISSN (On Line): 2665-4385

https://revistacolombianaentomologia.univalle.edu.co

Open access

(c) (i) (2) (2) BY-NC-SA 4.0

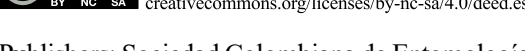

Publishers: Sociedad Colombiana de Entomología
SOCOLEN (Bogotá, D. C., Colombia) https://www.socolen.org.co

Universidad del Valle (Cali, Colombia)

https://www.univalle.edu.co

(C) 2021 Sociedad Colombiana de Entomología SOCOLEN y Universidad del Valle - Univalle
Abstract: Sewage sludge is a nitrogen-rich organic compound, which can be used to aid development in plants such as Platycyamus regnellii (Fabaceae), in the recovery of degraded areas. This study aimed to assess the bottom-up effects on leaf mass and percentage of ground cover (leaf litter, herbaceous plants, and grasses) in $P$. regnellii trees fertilized (or not) with dehydrated sewage sludge and arthropod communities over 24 months. Platycyamus regnellii trees fertilized with dehydrated sewage sludge presented significantly more leaves per branch, branches per tree, and a higher percentage of ground cover compared to unfertilized trees. Phenacoccus sp. (Pseudococcidae) was the most abundant phytophagous insect associated with $P$. regnellii trees. Fertilization did not affect the abundance, diversity, and species richness of Hemiptera phytophagous on $P$. regnellii trees. However, fertilized trees presented higher abundance and species richness of trophobiont-tending ants compared to unfertilized trees, with Camponotus sp. being the most abundant regardless of the treatment. Fertilized $P$. regnellii trees also presented higher species richness of natural enemies compared to unfertilized ones, with Aranae and Dolichopodidae being the most abundant. We concluded that fertilization with dehydrated sewage sludge improved $P$. regnellii trees leaf mass and ground cover and increased the diversity of trophobiont-tending ants and natural enemies. To our knowledge, this is the first study on the arthropods community associated with this tree species. This suggests that upon fertilization, $P$. renellii trees are useful for ecological restoration in severely disturbed areas.

Keywords: Arthropods, fertilization with sewage sludge, sucking insects, abundance of beneficial insects, trophobiont-tending ants, Platycyamus regnellii.

Resumen: El lodo de aguas residuales es un compuesto orgánico rico en nitrógeno que aumenta el desarrollo de plantas como Platycyamus regnellii (Fabaceae), que se usa comúnmente en la recuperación de áreas degradadas. Este estudio se centra en la evaluación de los efectos ascendentes en la producción en masa vegetal y la cobertura del suelo en plantas de $P$. regnellii fertilizados (o no) con lodo de aguas residuales y las comunidades de artrópodos durante 24 meses. Los árboles de P. regnellii fertilizados con lodo de aguas residuales presentaron significativamente más hojas por rama, ramas por árbol, y un mayor porcentaje de cobertura del suelo en comparación con los árboles no fertilizados. Phenacoccus sp. (Pseudococcidae) fue la especie fitófaga más abundante. La fertilización no afectó la abundancia, diversidad y riqueza de especies de Hemiptera fitófagos en árboles de $P$. regnellii. Sin embargo, los árboles fertilizados presentaron mayor abundancia y riqueza de especies de hormigas cuidadora de trofobiontes en comparación con los árboles no fertilizados. Camponotus sp. fue la specie más abundante independientemente del tratamiento. Los árboles de $P$. regnellii fertilizados también presentaron mayor riqueza de especies de enemigos naturales en comparación con los no fertilizados, siendo Aranae y Dolichopodidae los más abundantes. Se concluye que las 
coronas más grandes de $P$. regnellii fueron aquellas fertilizadas con lodo de aguas residuales deshidratadas, lo que aumenta la cobertura del suelo, la diversidad de hormigas cuidadoras de trofobiontes, y de enemigos naturales. Hasta donde se conoce, este es el primer estudio sobre la comunidad de artrópodos asociada a esta especie de árbol. Esto sugiere que las plantas de $P$. renellii fertilizadas con lodos de depurados son adecuadas para la recuperación de áreas degradadas.

Palabras clave: Artrópodos, fertilización con lodos depurados, insectos chupadores, abundancia de insectos benéficos, hormigas cuidadoras de trofobiontes, Platycyamus regnellii.

\section{Introduction}

Plants are primary producers that affect a wide range of different groups of organisms (e.g. phytophagous insects) in terrestrial food webs, providing them food and habitat. They are also present in resource-driven webs in which they provide profound bottom-up effects on higher trophic levels (Price 2002). Terrestrial food webs are composed of at least three interacting trophic levels: plants, herbivores, and natural enemies, and are controlled from the bottom-up via plant nutrition or from the top down via herbivory (Price et al. 1980; Rosemond et al. 1993). These hypotheses have been tested and empirically studied on two Quercus species, with fertilization used as the bottom-up effect, and the removal of natural enemies as top-down effects (Cornelissen and Stiling 2006). The authors found that fertilization affects herbivores density while the removal of natural enemies did not, suggesting that herbivores are more responsive to bottom-up compared to top-down effects.

Sewage sludge is a by-product from industrial or municipal waste treatment, rich in organic matter and, ideal for soil fertilization or substrate in seedling production (Antonkiewicz et al. 2019; Carvalho et al. 2020). This wasting product may be used in forest plantations and the recovery of degraded areas, ameliorating the risk of toxic elements entering the human food chain (Kimberley et al. 2004). Sewage sludge has the potential for usage as fertilizer in agriculture, and forests, reducing the production costs, the residual accumulation and environmental problems, and giving it an appropriate destination (Caldeira et al. 2014).

Platycyamus regnellii Benth (Fabaceae) is a native tree in Brazil, distributed in the states of Bahia, Minas Gerais, Espírito Santo, Rio de Janeiro, Paraná, São Paulo, and Goiás, especially in the semi-deciduous highland forests (Lorenzi 2008). This tree species is used in the reforestation of degraded areas and landscaping, ornamentation of parks and gardens (Brandão et al. 2002). Platycyamus regnellii has medicinal properties against fever, maldigestion, and inappetence, and is a proper wood for civil construction, carpentry, and manufacturing (Ferreira et al. 2015). Although there is a broad knowledge on its use as an ecological restorer, and other uses, little is known on the effects of sewage sludge on $P$. regnellii tree production and there are no studies on arthropods community associated with this tree species.

Sewage sludge increases humus content in the soil (Silva et al. 2011; Abreu et al. 2017) and is rich in phosphorus, nitrogen, macro $(\mathrm{Ca}, \mathrm{Mg})$, and micronutrients $(\mathrm{Cu}$ and $\mathrm{Zn})$ (Nogueira et al. 2007), which favors the plant development and, consequently, increases ecological indices of phytophagous insects ( $>$ biogeographic island - BGI) and their natural enemies (Auslander et al. 2003). Changes in soil fertility may directly affect the nutrition and chemical defenses of the host plant, and this impacts the diversity of phytophagous insects and their natural enemies (Cornelissen and Stiling 2006; Staley et al. 2010; Graff et al. 2020). Insects are very susceptible to environmental changes, and such can be useful for monitoring the recovery of degraded areas (Burgio et al. 2015).

While interactions in terrestrial food webs depend on bottom-up effects on plant and herbivore communities, these interactions and forest productivity are usually structured by mutualism between ants and sap-sucking insects (Clark et al. 2019). Ants are an important group of insects that affect the interactions in host plant-herbivore systems in different ways, by attacking herbivores whilst defending the trophobionts; as seen in the positive relationship between ants and herbivores trophobiont richness on Baccharis dracunculifolia DC (Asteraceae) (Monteiro et al. 2020). Trophobiont-tending ants, hereafter, are those who defend hemipterans in exchange for food (honeydew) (Freitas and Rossi 2015).

The aim here was to assess leaf mass production and percentage of ground cover (leaf litter, herbaceous plants, and grasses) of $P$. regnellii trees fertilized and unfertilized with dehydrated sewage sludge and associated arthropods community on the trees over 24 months. The assumptions in the study were that i) trees fertilized with sewage sludge would have larger canopies, and therefore, an increased ground cover; ii) trees fertilized with sewage sludge would have larger canopies ( $>$ BGI) and thus an increased abundance of phytophagous insects and iii) larger trees would have more trophobiont-tending ants and natural enemies attracted by phytophagous insects.

\section{Materials and methods}

Experimental site. The study was carried out in a degraded area at the "Instituto de Ciências Agrárias (ICA)" of the "Universidade Federal de Minas Gerais (UFMG)", Montes Claros, Minas Gerais State, Brazil (1651'38'S 4455'00'W, 943 m) during 24 months (March 2015 to February 2017). The degraded area has severe loss and changes in soil chemistry and hydrology. According to Köppen's climate classification, it is a tropical dry climate area with annual rainfall between 1000$1300 \mathrm{~mm}$, with dry winter and an annual mean temperature of $\geq 18^{\circ} \mathrm{C}$.

The soil is a litolic neosoil, loamy texture, total sand $=17$ dag. $\mathrm{Kg}^{-1}$, silt $=46.0$ dag. $\mathrm{Kg}^{-1}$, clay $=37.0$ dag. $\mathrm{Kg}^{-1}, \mathrm{pH}-\mathrm{H}_{2} \mathrm{O}$ $=4.3$, organic matter $=0.73$ dag. $\mathrm{Kg}^{-1}$, organic carbon $=0.42$ dag. $\mathrm{Kg}^{-1}, \mathrm{P}=0.35 \mathrm{mg} . \mathrm{dm}^{-3}, \mathrm{~K}=41.0 \mathrm{mg} . \mathrm{dm}^{-3}, \mathrm{Ca}=1.6$ $\mathrm{cmol}_{\mathrm{c}} \cdot \mathrm{dm}^{-3}, \mathrm{Mg}=0.9 \mathrm{cmol}_{\mathrm{c}} \cdot \mathrm{dm}^{-3}, \mathrm{Al}=3.3 \mathrm{cmol}_{\mathrm{c}} \cdot \mathrm{dm}^{-3}$, aluminum saturation in the capacity of cationic exchange $=55.1$ $\%$, sum of bases $=2.69 \mathrm{cmol}_{\mathrm{c}} \mathrm{dm}^{-3}, \mathrm{H}+\mathrm{Al}=13.4 \mathrm{cmol}_{\mathrm{c}} \cdot \mathrm{dm}$ -3 , percentage of soil base saturation of the capacity of cationic exchange a $\mathrm{pH} 7.0=16.7$, effective cation exchange capacity $(\mathrm{CEC})=5.9 \mathrm{cmol}_{\mathrm{c}} \cdot \mathrm{dm}^{-3}$, and potential $(\mathrm{pH} \mathrm{7.0)} \mathrm{CEC}=16.1$ $\mathrm{cmol}_{\mathrm{c}} \cdot \mathrm{dm}^{-3}$.

Experimental design. Platycyamus regnellii seedlings were produced from seeds of trees grown at the ICA/UFMG. Seedlings were planted in March 2014, in plastic bags (8 x $12 \mathrm{~cm}$ ) in a nursery, with a substrate (160 g per seedling) containing $30 \%$ of organic compost (two parts of debris gardening pruning and one-part bovine manure), $30 \%$ of clay soil, $30 \%$ of sand, and $10 \%$ of reactive natural phosphate. The $\mathrm{pH}$ soil was corrected with dolomitic limestone (90\% relative total neutralization power) (187 g per pit), increasing base saturation to $50 \%$. Natural phosphate ( $80 \mathrm{~g}$ per pit), fritted trace 
elements ( $10 \mathrm{~g}$ per pit), and marble rock dust ( $1 \mathrm{Kg}$ per pit) were added according to soil analysis. In September 2014, 48 $P$. regnellii seedlings $(30 \mathrm{~cm}$ height $)$ were planted in pits $(40 \times$ $40 \times 40 \mathrm{~cm}$ ) spaced two meters from each other, in six parallel lines (two meters between lines) with four seedlings per line. The seedlings were, fertilized with $20 \mathrm{~L}$ (in a single dose) of dehydrated sewage sludge, while a control group remained unfertilized. The seedlings were watered twice a week until the beginning of the rainy season and were pruned up to $1 / 3$ of the canopy, eliminating $5 \mathrm{~cm}$ long branches. The experimental design was completely randomized with two factors (fertilized or unfertilized) of the treatment and 24 replicates.

Sewage sludge. Dehydrated sewage sludge with $5 \%$ moisture content was collected at the sewage treatment plant - "Estação de Tratamento de Esgoto (ETE)" in Juramento, state of Minas Gerais, Brazil. The ETE treats $217 \mathrm{~m}^{3}$ sewage per day with an efficiency of organic matter removal of $\sim 90 \%$. The sewage sludge treatment occurs via solarization in coarse sand tanks for three months, and it aims to reduces the thermotolerant coliforms to acceptable levels $\left(<10^{3}\right.$ coliforms number/g of total solids) for use in agriculture (CONAMA, Resolution N375, Brazil). Chemical and biological characteristics of the dehydrated sewage sludge are $\mathrm{pH}-\mathrm{H}_{2} \mathrm{O}=4.40, \mathrm{~N}=10.4 \mathrm{mg} . \mathrm{Kg}$ ${ }^{-1}, \mathrm{P}=2.9 \mathrm{mg} \cdot \mathrm{Kg}^{-1}, \mathrm{~K}=5.8 \mathrm{mg} \cdot \mathrm{Kg}^{-1}, \mathrm{Cd}=0.1 \mu \mathrm{g} \cdot \mathrm{g}^{-1}, \mathrm{~Pb}=$ $56.9 \mu \mathrm{g} \cdot \mathrm{g}^{-1}, \mathrm{Cr}=46.7 \mu \mathrm{g} \cdot \mathrm{g}^{-1}$, and fecal coliforms $=4.35 \mathrm{most}$ likely number $\mathrm{g}^{-1}$ (Nogueira et al. 2007).

Leaf mass production and ground cover. Leaves per branch, branches per tree numbers, and the percentage of ground cover by litter, grass, and herbaceous plants, were measured monthly by visual observation on $1.0 \mathrm{~m}^{2}$ plots at the canopy projection of six-months-old $P$. regnellii trees.

Arthropods. The arthropods counting was done biweekly in the mornings (7:00 to 11:00 AM) by visual observations on the adaxial and abaxial faces (12 leaves/tree/survey), on apical, middle, and basal canopy parts in the northerly, southerly, easterly, and westerly directions, totalizing 27,648 leaves during all experimental period. At least three specimens per arthropod species were captured with aspirator, put in glass flasks with $70 \%$ ethanol, and sent for identification.

Data analysis. The mean data (i.e. 12 leaves/tree/survey) from single trees was used. Data on leaf mass production (leaves per branch and branches per tree) and ground cover (percentages of cover by litter, grass, and herbaceous plants) were submitted to analysis of variance (one-way ANOVA) and means were compared using the Tukey range test $(\mathrm{P}<$ 0.05). Ecological indices (abundance, diversity, and species richness) were calculated per group of arthropods (i.e. hemipteran, trophobiont-tending ants, and natural enemies) and treatment (fertilization or not with dehydrated sewage sludge) using BioDiversity Professional, Version 2. The diversity was calculated with Hill's formula and species richness with Simpson indices. The abundance, diversity, and species richness of phytophagous Hemiptera, trophobiont-tending ants, and natural enemies were submitted to the non-parametric statistical hypothesis Wilcoxon signed-rank test $(\mathrm{P}<0.05)$. Throughout the text, means \pm standard errors (S.E.) are presented. All analyses were conducted in "Sistema para Análises Estatísticas e Genéticas" (Sistema para Análises Estatísticas 2007), version 9.1. Regression analysis was performed for ecological indi- ces of phytophagous Hemiptera against trophobiont-tending ants and natural enemies in SAEG $(\mathrm{P}<0.05)$.

\section{Results}

Leaf mass production and ground cover. Platycyamus regnellii trees fertilized with dehydrated sewage sludge produced significantly $(\mathrm{P}<0.05)$ more leaves per branch, branches per tree, as well as more percentage of ground cover (leaf litter, herbaceous plants, and grasses) compared to unfertilized ones (Table 1).

Arthropods. No differences $(\mathrm{P}>0.05)$ in abundance, diversity, and species richness of phytophagous Hemiptera were observed between fertilized and unfertilized trees. However, Phenacoccus sp. (Hemiptera: Pseudococcidae) was the most abundant phytophagous insect collected and was found exclusively on fertilized trees $(1.46 \pm 1.01)$. Trophobiont-tending ants presented a higher abundance $(\mathrm{P}=0.02)$ and species richness $(\mathrm{P}=0.02)$ on leaves of fertilized $P$. regnellii trees $(0.63 \pm$ 0.18 and $0.58 \pm 0.15$, respectively) compared to those unfertilized $(0.25 \pm 0.13$ and $0.21 \pm 0.10$, respectively). Camponotus sp. (Hymenoptera: Formicidae) was the most abundant ( $\mathrm{P}=$ 0.11 ) trophobiont-tending ants on fertilized $P$. regnellii trees, regardless of the treatment (fertilized $=0.21 \pm 0.08$ and unfertilized $=0.08 \pm 0.05$ ). Natural enemies presented the highest indices of species richness $(\mathrm{P}=0.03)$ on fertilized trees $(1.63$ $\pm 0.36)$ compared to unfertilized $(0.75 \pm 0.16)$ ones; no other ecological indices were affected by tree fertilization $(\mathrm{P}>$ $0.05)$. Although there was no significant difference $(\mathrm{P}>0.05)$ between treatments, Aranae and Dolichopodidae (Diptera) were the most abundant natural enemies on fertilized (2.75 \pm 1.89 and $0.21 \pm 0.13$, respectively) and on unfertilized ( 0.58 \pm 0.16 and $0.13 \pm 0.06$, respectively) $P$. regnellii trees (Table 2). The increase in abundance of trophobiont-tending ants positively affected the abundance of phytophagous Hemiptera $\left(y^{\prime}=3.19+8.66 x, R^{2}=0.14, F=7.26, P=0.01\right)$.

\section{Discussion}

We found that fertilization with dehydrated sewage sludge improved $P$. regnellii trees leaf mass and ground cover and increased the diversity of trophobiont-tending ants and natural enemies. To our knowledge, this is the first study on the arthropods community associated with this tree species. Dehydrated sewage sludge fertilization favored the development of $P$. regnellii trees as this organic waste product is rich in nitrogen (Nogueira et al. 2007). Trees fertilized with

Table 1. Mean \pm SE of leaf mass (leaves per branch and branches per tree) and percentage of ground cover (leaf litter, herbaceous plants, and grasses) of Platycyamus regnellii Benth. (Fabaceae) trees fertilized and unfertilized with dehydrated sewage sludge.

\begin{tabular}{lcccc}
\hline & \multicolumn{2}{c}{ Sewage sludge } & \multicolumn{2}{c}{ ANOVA } \\
\cline { 2 - 5 } & fertilized & Control & F & P \\
\hline Leaves per branch & $7.56 \pm 0.29 \mathrm{a}$ & $5.58 \pm 0.23 \mathrm{~b}$ & 16.7 & 0.00 \\
Branches per tree & $4.54 \pm 0.14 \mathrm{a}$ & $3.06 \pm 0.11 \mathrm{~b}$ & 16.8 & 0.00 \\
Ground cover (\%) & $25.09 \pm 1.20 \mathrm{a}$ & $6.32 \pm 0.46 \mathrm{~b}$ & 62.6 & 0.00 \\
\hline
\end{tabular}

Means followed by the same letter ( \pm standard error) per line are not different by the test of Tukey. F and P values were obtained by ANOVA. Degrees of freedom of treatments and errors were 1 and 23 , respectively. $\mathrm{N}=24$ per treatment. 
Table 2. Mean \pm SE of abundance (Abun.), diversity (D.), and species richness (S.R.) of phytophagous Hemiptera (Hem.), trophobiont-tending ants (Ants) and natural enemies (N.E.), and numbers of species of insects on Platycyamus regnellii Benth. (Fabaceae) trees fertilized and unfertilized with dehydrated sewage sludge. Ecological indices (abundance, diversity, and species richness) were calculated per group of arthropods (i.e. hemipteran, trophobiont-tending ants, and natural enemies) and treatment (fertilization or not with dehydrated sewage sludge).

\begin{tabular}{lcccc}
\hline & \multicolumn{2}{c}{ Sewage sludge } & \multicolumn{2}{c}{ Wilcoxon test } \\
\cline { 2 - 5 } & Fertilized & Control & VT* & P \\
\hline Abund. Hem. & $1.96 \pm 1.00$ & $1.08 \pm 0.51$ & 0.5 & 0.31 \\
D. Hem. & $0.18 \pm 0.09$ & $0.28 \pm 0.17$ & 0.1 & 0.48 \\
S.R. Hem. & $0.58 \pm 0.16$ & $0.38 \pm 0.11$ & 0.7 & 0.25 \\
Aleyrodidae & $0.13 \pm 0.09$ & $0.88 \pm 0.51$ & 0.9 & 0.18 \\
Cicadellidae: Balclutha hebe (Kirkaldy, 1906) & $0.04 \pm 0.04$ & $0.04 \pm 0.04$ & 0.0 & 0.50 \\
Erythrogonia sexguttata (Fabr., 1803) & $0.04 \pm 0.04$ & $0.00 \pm 0.00$ & 1.0 & 0.16 \\
Nogodinidae: Bladina sp. & $0.04 \pm 0.04$ & $0.00 \pm 0.00$ & 1.0 & 0.16 \\
Pentatomidae & $0.25 \pm 0.10$ & $0.17 \pm 0.07$ & 0.4 & 0.34 \\
Pseudococcidae: Phenacoccus sp. & $1.46 \pm 1.01$ & $0.00 \pm 0.00$ & 1.4 & 0.08 \\
Abun. Ants & $0.63 \pm 0.18$ & $0.25 \pm 0.13$ & 2.1 & 0.02 \\
D. Ants & $0.33 \pm 0.27$ & $0.12 \pm 0.08$ & 0.0 & 0.48 \\
S.R. Ants & $0.58 \pm 0.15$ & $0.21 \pm 0.10$ & 2.1 & 0.02 \\
Abun. N.E. & $3.67 \pm 1.90$ & $0.96 \pm 0.23$ & 1.5 & 0.07 \\
D. N.E. & $2.33 \pm 0.95$ & $1.02 \pm 0.34$ & 0.5 & 0.31 \\
S.R. N.E. & $1.63 \pm 0.36$ & $0.75 \pm 0.16$ & 1.9 & 0.03 \\
Araneae & $2.75 \pm 1.89$ & $0.58 \pm 0.16$ & 0.9 & 0.19 \\
Diptera: Dolichopodidae & $0.21 \pm 0.13$ & $0.13 \pm 0.06$ & 0.1 & 0.48 \\
Hymenoptera: Braconidae & $0.04 \pm 0.04$ & $0.00 \pm 0.00$ & 1.0 & 0.16 \\
Formicidae: Brachymyrmex sp. & $0.04 \pm 0.04$ & $0.08 \pm 0.08$ & 0.03 & 0.49 \\
Camponotus sp. & $0.21 \pm 0.08$ & $0.08 \pm 0.05$ & 1.2 & 0.11 \\
Cephalotes sp. & $0.08 \pm 0.08$ & $0.00 \pm 0.00$ & 1.0 & 0.16 \\
Ectatoma sp. & $0.08 \pm 0.05$ & $0.00 \pm 0.00$ & 1.4 & 0.08 \\
Pheidole sp. & $0.04 \pm 0.04$ & $0.00 \pm 0.00$ & 1.0 & 0.16 \\
Pseudomyrmex termitarius (Smith, F., 1855) & $0.17 \pm 0.07$ & $0.08 \pm 0.05$ & 0.9 & 0.19 \\
\hline N 24 per trat.yyyyyyyyy
\end{tabular}

$\mathrm{N}=24$ per treatment. $V T^{(*)}=$ value of the test.

dehydrated sewage sludge had larger canopy width (> BGI) that results in more food resources for phytophagous insects (Ferrier and Price 2004; Leite et al. 2017). In our study, the most abundant herbivorous insect was found exclusively on fertilized plants, attracting more trophobiont-tending ants and natural enemies (Auslander et al. 2003) compared to unfertilized trees (as seen in the positive regression).

Platycyamus regnellii trees fertilized with sewage sludge developed better, i.e. they had a higher number of leaves $(>1.4)$ and branches $(>1.5)$, and this reflected in a higher percentage of ground cover $(>3.9)$ compared to unfertilized trees. This confirms the first assumption that fertilization with dehydrated sewage sludge on $P$. regnellii trees would speed up the recovery process of degraded areas by increasing soil fertility and decrease laminar erosion (Franco et al. 2002). The recovery of degraded areas is a slow process (Ferreira et al. 2007), so the use of fertilization such as organic waste products on $P$. regnellii trees is promising. In fact, sewage sludge has been broadly used for fertilization of arboreal species such as Araucaria angustifolia (Bertol) Kuntze (Araucariaceae), Cedrela fissilis Vell (Meliaceae), Eucalyptus grandis Hill (Myrtaceae), Lafoensia pacari Saint-Hilaire (Lythraceae) and Senna spectabilis Schrad (Fabaceae) (Silva et al. 2011; Abreu et al. 2017) and also for natural regeneration in riparian forests (Campos and Landgraf 2001).

The fact that twice as many insects were observed on fertilized $P$. regnellii trees (in absolute numbers) probably was due to the higher amount and quality of leaves, which are food resources to phytophagous insects. This confirms the second assumption that the abundance of hemipterans is usually higher in trees with higher leaf mass (Ferrier and Price 2004; Leite et al. 2017). Furthermore, the amount of free amino acids and protein in leaf sap usually increases with nitrogen fertilization on trees, thus favoring sucking insects (Taiz et al. $2017)$ such as Phenacoccus sp. $(\approx 1.5$ insects per tree). Sewage sludge used as biofertilizer is also helpful in the ecological recovery of macrofauna, including larvae and adults of Scarabaeidae (Coleoptera) in degraded areas of Cerrado (Kitamura et al. 2008).

The highest abundance and species richness of trophobiont-tending ants and species richness of total natural enemies, including spiders, were observed on fertilized $P$. regnellii trees compared to those unfertilized, with a positive correlation between phytophagous (sucking) insects. The results confirm the third assumption that trees with larger canopy width (> BGI) would have more trophobiont-tending ants (e.g. Camponotus sp. and Cephalotes sp.) and natural enemies attracted by sucking insects. This tritrophic interaction among plants $=>$ sap-sucking insects $=>$ trophobiont-tending ants is one of the most critical interactions found in nature (Stadler and Dixon 2005; Araujo et al. 2016). The presence of trophobiont-tending ants on $P$. regnellii trees is likely due to a mutualistic relationship with phytophagous insects such as Hemiptera (Stadler and Dixon 2005; Araujo et al. 2016). Beyond the ecological importance, ants are also used as bioindicators of ecological restoration of degraded areas 
as they respond quickly to environmental changes (Chomicki et al. 2015).

Platycyamus regnellii fertilized with dehydrated sewage sludge had larger canopy width (higher number of leaves and branches) that favors ground cover. Bigger and leafy trees could present a better resource for phytophagous (sucking) insects, such as hemipterans, which in turn attract a greater abundance and richness of trophobiont-tending ants and richness of species of natural enemies. To our knowledge, this is the first study on arthropods communities associated with this tree species. It suggests that, upon fertilization, $P$ regnellii is an adequate option for the recovery of degraded areas as it developed faster and favored the local biodiversity.

\section{Acknowledgements}

To Dr. Carlos Augusto Rodrigues Matrangolo (Universidade Estadual de Montes Claros, Janaúba, Minas Gerais, BrazilFormicidae), Dr. Ivan Cardoso Nascimento (Universidade Estadual do Sudoeste da Bahia, Jequié, Bahia, Brazil - Formicidae), Dr. Luci Boa Nova Coelho (Universidade Federal do Rio de Janeiro, Rio de Janeiro, Brasil - Cicadellidae), and Dr. Paulo Sérgio Fiuza Ferreira (UFV, Viçosa, Minas Gerais, Brazil - Hemiptera) for insect species identifications. The voucher numbers for insects is 1595/02 and 1597/02 (Centro de Estudos Faunísticos e Ambientais, Universidade Federal do Paraná, Curitiba, Paraná, Brazil).

\section{Literature cited}

ABREU, A. H. M.; MARZOLA, L. B.; MELO, L. A.; LELES, P. S. D. S.; ABEL, E. L. S.; ALONSO, J. M. 2017. Urban solid waste in the production of Lafoensia pacari seedlings. Revista Brasileira de Engenharia Agrícola e Ambiental 21 (2): 83-87. https:// doi.org/10.1590/1807-1929/agriambi.v21n2p83-87

ANTONKIEWICZ, J.; BARAN, A.; PEŁKA, R.; WISŁA-ŚWIDER, A.; NOWAK, E.; KONIECZKA, P. 2019. A mixture of cellulose production waste with municipal sewage as new material for an ecological management of wastes. Ecotoxicology and Environmental Safety 169: 607-614. https://doi.org/10.1016/j. ecoenv.2018.11.070

ARAUJO, E. S.; BENATTO, A.; MÓGOR, Á. F.; PENTEADO, S. C.; ZAWADNEAK, M. A. C. 2016. Biological parameters and fertility life table of Aphis forbesi Weed, 1889 (Hemiptera: Aphididae) on strawberry. Brazilian Journal of Biology 76 (4): $937-$ 941. https://doi.org/10.1590/1519-6984.04715

AUSLANDER, M.; NEVO, E.; INBAR, M. 2003. The effects of slope orientation on plant growth, developmental instability and susceptibility to herbivores. Journal of Arid Environments 55 (3): 405-416. https://doi.org/10.1016/S0140-1963(02)00281-1

BRANDÃO, M.; LACA-BUENDÍA, J. P.; MACEDO, J. F. 2002. Árvores nativas e exóticas do Estado de Minas Gerais. Belo Horizonte: EPAMIG. Minas Gerais, Brazil. 528 p.

BURGIO, G.; SOMMAGGIO, D.; MARINI, M.; PUPPI, G.; CHIARUCCI, A.; LANDI, S.; FABBRI, R.; PERSARINI, F.; GENGHINI, M.; FERRARI, R.; MUZZI, E.; LENTEREN, J. C.; MASETTI, A. 2015. The influence of vegetation and landscape structural connectivity on butterflies (Lepidoptera: Papilionoidea and Hesperiidae), carabids (Coleoptera: Carabidae), syrphids (Diptera: Syrphidae), and sawflies (Hymenoptera: Symphyta) in northern Italy farmland. Environmental Entomology 44 (5): 1299-1307. https://doi.org/10.1093/ee/nvv105

CALDEIRA, M. V. W.; FAVALESSA, M.; GONÇALVES, E. O.; DELARMELINA, W. M.; SANTOS, F. E. V.; VIERA, M. 2014. Lodo de esgoto como componente de substrato para produção de mudas de Acacia mangium Wild. Comunicata Scientiae 5 (1): 3443. https://dialnet.unirioja.es/servlet/articulo? codigo $=5022030$

CAMPOS, J. C.; LANDGRAF, P. R. C. 2001. Análise da regeneração natural de espécies florestais em matas ciliares de acordo com a distância da margem do lago. Ciência Florestal 11 (2): 143-151. https://doi.org/10.5902/198050981662

CARVALHO, J. C. N.; SILVA, F. W. S.; LEITE, G. L. D.; AZEVEDO, A. M.; TEIXEIRA, G. L.; SOARES, M. A.; ZANUNCIO, J. C.; LEGASPI, J. C. 2020. Does fertilization with dehydrated sewage sludge affect Terminalia argentea (Combretaceae) and associated arthropods community in a degraded area? Scientific Reports 10: 11811. https://doi.org/10.1038/s41598-020-68747-z

CHOMICKI, G.; WARD, P. S.; RENNER, S. S. 2015. Macroevolutionary assembly of ant/plant symbioses: Pseudomyrmex ants and their ant-housing plants in the Neotropics. Proceedings of the Royal Society B - Biological Sciences 282: 20152200. https://doi.org/10.1098/rspb.2015.2200

CLARK, R. E.; GUTIERREZ ILLAN, J.; COMERFORD, M. S.; SINGER, M. S. 2019. Keystone mutualism influences forest tree growth at a landscape scale. Ecology Letters 22 (10): 1599-1607. https://doi.org/10.1111/ele.13352

CORNELISSEN, T.; STILING, P. 2006. Responses of different herbivore guilds to nutrient addition and natural enemy exclusion. Écoscience 13 (1): 66-74. https://doi.org/10.2980/1195-6860(20 06)13[66:RODHGT]2.0.CO;2

FERREIRA, W. C.; BOTELHO, S. A.; DAVIDE, A. C.; FARIA, J. M. R. 2007. Avaliação do crescimento do estrato arbóreo de área degradada revegetada à margem do Rio Grande, na Usina Hidrelétrica de Camargos, MG. Revista Árvore 31 (1): 177-185. https://doi.org/10.1590/S0100-67622007000100020

FERREIRA, M. C.; COSTA, S. M. L.; PASIN, L. A. A. 2015. Uso de resíduos da agroindústria de bananas na composição de substratos para produção de mudas de pau pereira. Nativa 3 (2): 120124. https://doi.org/10.14583/2318-7670.v03n02a08

FERRIER, S. M.; PRICE, P. W. 2004. Oviposition preference and larval performance of a rare bud-galling sawfly (Hymenoptera: Tenthredinidae) on willow in northern Arizona. Environmental Entomology 33 (3): 700-708. https://doi.org/10.1603/0046-225X-33.3.700

FRANCO, F. S.; COUTO, L.; CARVALHO, A. F.; JUCKSCH, I.; FILHO, E. I. F.; SILVA, E.; MEIRA NETO, J. A. A. 2002. Quantificação de erosão em sistemas agroflorestais e convencionais na Zona da Mata de Minas Gerais. Revista Árvore 26 (6): 751-760. https://doi.org/10.1590/S0100-67622002000600011

FREITAS, J. D.; ROSSI, M. N. 2015. Interaction between trophobiont insects and ants: the effect of mutualism on the associated arthropod community. Journal of Insect Conservation 19: 627638. https://doi.org/10.1007/s10841-015-9785-2

GRAFF, P.; GUNDEL, P. E.; SALVAT, A.; CRISTOS, D.; CHANETON, E. J. 2020. Protection offered by leaf fungal endophytes to an invasive species against native herbivores depends on soil nutrients. Journal of Ecology 108 (4): 1592-1604. https://doi. org/10.1111/1365-2745.13371

KIMBERLEY, M. O.; WANG, H.; WILKS, P. J.; FISHER, C. R.; MAGESAN, G. N. 2004. Economic analysis of growth response from a pine plantation forest applied with biosolids. Forest Ecology and Management 189 (1-3): 345-351. https://doi.org/10.1016/j.foreco.2003.09.003

KITAMURA, A. E.; ALVES, M. C.; SUZUKI, L. G. A. S.; PAZ GONZÁLEZ, A. 2008. Recuperação de um solo degradado com a aplicação de adubos verdes e lodo de esgoto. Revista Brasileira de Ciência do Solo 32 (1): 405-416. https://doi.org/10.1590/ S0100-06832008000100038

LEITE, G. L. D.; VELOSO, R. V. S.; ZANUNCIO, J. C.; AZEVEDO, A. M.; SILVA, J. L.; WILCKEN, C. F.; SOARES, M. A. 2017. Architectural diversity and galling insects on Caryocar brasiliense trees. Scientific Reports 7: 16677. https://doi. org/10.1038/s41598-017-16954-6 
LORENZI, H. 2008. Árvores brasileiras: manual de identificação e cultivo de plantas arbóreas nativas do Brasil. Instituto Plantarum de Estudos da Flora. Nova Odessa, Brasil. 384 p.

MONTEIRO, G. F.; MACEDO-REIS, L. E.; DÁTTILO, W.; FERNANDES, G. W.; CASTRO, F. S.; NEVES, F. S. 2020. Ecological interactions among insect herbivores, ants and the host plant Baccharis dracunculifolia in a Brazilian mountain ecosystem. Austral Ecology 45 (2): 158-167. https://doi.org/10.1111/ aec. 12839

NOGUEIRA, T. A. R.; SAMPAIO, R. A.; FONSECA, I. M.; FERREIRA, C. S.; SANTOS, S. E.; FERREIRA, L. C.; GOMES, E.; FERNANDES, L. A. 2007. Metais pesados e patógenos em milho e feijão caupi consorciados, adubados com lodo de esgoto. Revista Brasileira de Engenharia Agrícola e Ambiental 11 (3): 331-338. https://doi.org/10.1590/S1415-43662007000300014

PRICE, P. W. 2002. Resource-driven terrestrial interaction webs. Ecological Research 17 (2): 241-247. https://doi.org/10.1046/ j.1440-1703.2002.00483.X

PRICE, P. W.; BOUTON, C. E.; GROSS, P.; McPHERON, B. A.; THOMPSON, J. N.; WEIS, A. E. 1980. Interactions Among Three Trophic Levels: Influence of Plants on Interactions Between Insect Herbivores and Natural Enemies. Annual Review of Ecology and Systematics 11: 41-65. https://doi.org/10.1146/ annurev.es.11.110180.000353

ROSEMOND, A. D.; MULHOLLAND, P. J.; ELWOOD. J. W. 1993. Top-down and bottom-up control of stream periphyton: effects of nutrients and herbivores. Ecology 74 (4): 1264-1280. https:// doi.org/10.2307/1940495

SILVA, P. H. M.; POGGIANI, F.; LACLAU, J. P. 2011. Applying sewage sludge to Eucalyptus grandis plantations: effects on biomass production and nutrient cycling through litterfall. Applied and Environmental Soil Science 2011: 1-11. https://doi. org/10.1155/2011/710614

SISTEMA PARA ANÁLISES ESTATÍSTICAS (SAEG). 2007. Versão 9.1. Fundação Arthur Bernardes - UFV - Viçosa. Review date: 1th January 2018. Available in: http://arquivo.ufv.br/saeg/

STADLER, B.; DIXON, A. F. G. 2005. Ecology and evolution of aphid-ant interactions. Annual Review of Ecology, Evolution and Systematics 36: 345-372. https://doi.org/10.1146/annurev. ecolsys.36.091704.175531

STALEY, J. T.; STEWART-JONES, A.; POPE, T. W.; WRIGHT, D. J.; LEATHER, S. R.; HADLEY, P.; ROSSITER, J. T.; VAN EMDEN, H. F.; POPPY, G. M. 2010. Varying responses of insect herbivores to altered plant chemistry under organic and conventional treatments. Proceedings of the Royal Society B 277 (1682): 779-786. https://doi.org/10.1098/rspb.2009.1631

TAIZ, L.; ZEIGER, E.; MOLLER, I. M.; MURPHY, A. (Eds.). 2017. Fisiologia e desenvolvimento vegetal. 6th Edition. Artmed: Porto Alegre. São Paulo, Brazil. 858 p. https://grupos. moodle.ufsc.br/pluginfile.php/474835/mod resource/content $/ 0 /$ Fisiologia $\% 20 \mathrm{e} \% 20$ desenvolvimento $\% 20$ vegetal $\% 20-\% 20$ Zair\%206\%C2\%AAed.pdf

\section{Origin and funding}

This work is part of MSc studies and was funded by the Brazilian agencies "Conselho Nacional de Desenvolvimento Cientifico e Tecnológico (CNPq)" and "Fundação de Amparo à Pesquisa do Estado de Minas Gerais (FAPEMIG)”.

\section{Author Contribution}

Gezilene Fernandes de Souza, Farley William Souza Silva and Júlia Letícia Silva carried out the experiments.

Gezilene Fernandes de Souza and Germano Leão Demolin Leite analyzed the data and performed the interpretation of the results.

Gezilene Fernandes de Souza, Germano Leão Demolin Leite, Farley William Souza Silva, Júlia Letícia Silva,

Marcus Alvarenga Soares, Gustavo Leal Teixeira, Regynaldo Arruda Sampaio, and José Cola Zanuncio wrote the manuscript.

Germano Leão Demolin Leite and Gustavo Leal Teixeira translated to English.

Germano Leão Demolin Leite, Regynaldo Arruda Sampaio, and José Cola Zanuncio supervised the project. 